\title{
A new species of the armored catfish Parotocinclus (Loricariidae: Hypoptopomatinae), from the Amazon basin in Colombia
}

\author{
Pablo Lehmann A. ${ }^{1}$, Lucas J. Schvambach ${ }^{1}$ and Roberto E. Reis ${ }^{2}$
}

A new species of hypoptopomatine cascudinho is described from a creek tributary to the Amazon River in Leticia, Amazonas Departament, Colombia. The new species of Parotocinclus is distinguished from congeners from northeastern to southeastern Brazilian rivers in having the cheek canal plate elongated posteriorly on the ventral surface of head and contacting the cleithrum. It is diagnosed from $P$. collinsae (Essequibo River basin, Guiana) and $P$. halbothi (rio Trombetas basin, Brazil and Marowijne River, Suriname), by having a triangular patch of dark pigmentation on the anterior portion of the dorsal-fin membrane, by the absence of unicuspid accessory teeth on both the premaxilla and dentary, and by having a Y-shaped light mark on the snout. The new species of Parotocinclus is distinguished from all remaining congeners by having a pigmentation pattern consisting of conspicuous dark dots smaller than a pupil diameter, broadly distributed dorsally and ventrally.

Uma espécie nova de cascudinho hypoptopomatíneo é descrita de um igarapé afluente do rio Amazonas em Leticia, Departamento Amazonas, Colômbia. A espécie nova de Parotocinclus é diagnosticada de suas congêneres do nordeste e sudeste do Brasil por ter a placa com canal da bochecha alongada posteriormente na superfície ventral da cabeça e em contato com o cleitro. A espécie nova é diagnosticada de $P$. collinsae (bacia do rio Essequibo, Guiana) e P. halbothi (bacia do rio Trombetas, Brasil e rio Marowijne, Suriname), por possuir uma mancha de pigmentação escura triangular na porção anterior da membrana da nadadeira dorsal, pela falta de dentes acessórios unicúspides na pré-maxila e no dentário, e por possuir uma mancha clara em forma de Y no focinho. A espécie nova de Parotocinclus se distingue das demais congêneres por possuir um padrão de pigmentação do corpo consistindo de conspícuos pontos escuros menores do que um diâmetro da pupila, amplamente distribuídos dorsal e ventralmente.

Keywords: Biodiversity, Freshwater, Leticia, Systematics, Taxonomy.

\section{Introduction}

The genus Parotocinclus Eigenmann \& Eigenmann, 1889 includes some of the smallest known loricariids and comprises 27 species of hypoptopomatine cascudinhos distributed across cis-Andean South America from Colombia and Venezuela to southern Brazil (Lehmann \& Reis, 2012; Lehmann et al., 2013). The new species described herein is a member of the clade that inhabits the Amazon and Orinoco River drainages and coastal basins of the Guianas ( $P$. amazonensis Garavello, 1977, P. britskii Boeseman, 1974, P. collinsae Schmidt \& Ferraris, 1985, P. eppleyi Schaefer \& Provenzano, 1993, P. halbothi Lehmann, Lazzarotto \& Reis, 2014, P. longirostris Garavello, 1988 and $P$. polyochrus Schaefer, 1988) (Lehmann et al., 2014). This clade is diagnosed by, among other characters, the canal cheek plate on the ventral surface of the head being elongated posteriorly and contacting the cleithrum, the head and snout being elongated and with a Y-shaped, white or cream colored mark dorsally, and the possession of a triangular dark blotch at the anterior base of the dorsal fin (last two features absent in $P$. collinsae and $P$. halbothi).

This new species was first recorded with a brief description and color illustration by Galvis et al. (2006) as Parotocinclus sp. nov., who mentioned that it was under description by one of us (PLA). In this paper we formally describe that species.

${ }^{1}$ Laboratório de Ictiologia, Universidade do Vale do Rio dos Sinos. Av. Unisinos, 950, 93022-000 São Leopoldo-RS, Brazil. (PL) pablole@unisinos.br, (LJS) schvambach@gmail.com

${ }^{2}$ Laboratório de Sistemática de Vertebrados, Pontifícia Universidade Católica do Rio Grande do Sul. P. O. Box 1429, $90619-900$ Porto Alegre-RS, Brazil. reis@pucrs.br 


\section{Material and Methods}

Comparative material examined is listed in Lehmann \& Reis (2012) and Lehmann et al. (2014). For the anatomical analysis, specimens were cleared and stained (c\&s) for visualization of bones and cartilages following the protocol of Taylor \& Van Dyke (1985). Illustrations were prepared under a stereomicroscope with a camera lucida and edited electronically. Measurements were taken as point-to-point linear distances with digital calipers under a dissecting scope on the left side of individuals, and recorded to the nearest $0.1 \mathrm{~mm}$, following mainly Boeseman (1968) and Schaefer (1997). Measurements are expressed as percents of standard length (SL) or head length (HL). Identification and counts of dermal plates follow the serial homology scheme proposed by Schaefer (1997). Vertebral counts include the five centra included in the Weberian Apparatus. In the description, counts of the holotype are presented in parentheses followed by the range of all type specimens. Dermal plates and vertebral centra were counted from c\&s material. Type specimens and comparative material are deposited in the Museo de Historia Natural, Instituto de Ciencias Naturales, Universidad Nacional de Colombia, Bogotá (ICNMHN) and the Museu de Ciências e Tecnologia da Pontifícia Universidade Católica do Rio Grande do Sul, Porto Alegre (MCP).

\section{Results}

\section{Parotocinclus variola, new species}

urn:1sid:zoobank.org:act:83E 85E43-C629-41B3-913F2E9558ADEC35

Figs. 1-2

Parotocinclus sp. nov. -Galvis et al., 2006: 351 (brief description, Fig. 97b).

Holotype. ICNMHN 18685, 25.9 mm SL, male, Colombia, Departamento Amazonas, Leticia, Quebrada Tacana, tributary to rio Amazonas at $\mathrm{km} 6.5$ of road from Leticia to Tarapacá, 409’15”S 6956’09”W, 22 Jul 2002, C. A. Pinto.

Paratypes. MCP 48245 (formerly ICNMHN 10085), 4, 22.2-29.3 mm SL + 2 c\&s, 26.5-27.2 mm SL +1 juv., 16.7 $\mathrm{mm} \mathrm{SL}$, collected with the holotype. MCP 48244 (formerly ICNMHN 10293), 5, 23.2-25.9 mm SL, Jan 2002, same locality as the holotype, C. A. Pinto. ICNMHN 10114, 5, 19.3-27.4 mm SL + 1 juv. $9.8 \mathrm{~mm}$ SL and ICNMHN 10349, 10, (5 measured, 20.2-27.7 mm SL), 31 May 2002, same locality as the holotype, C. A. Pinto. ICNMHN 10326, 3, 22.5-25.0 mm SL, Dec 2002, same locality as the holotype, C. A. Pinto.

Diagnosis. Parotocinclus variola is distinguished from congeners from northeastern to southeastern Brazilian rivers in having the cheek canal plate elongated posteriorly on the ventral surface of head and contacting the cleithrum ( $v s$. canal plate not elongated posteriorly and not contacting the pectoral girdle). It differs from $P$. collinsae (Essequibo River basin, Guiana) and $P$. halbothi (rio Trombetas basin, Brazil and Marowijne River, Suriname), by having a triangular patch of dark pigmentation on the anterior portion of the dorsal-fin membrane ( $v s$. the absence of such pigmentation), the absence of unicuspid accessory teeth on both the premaxilla and dentary ( $v s$. accessory teeth present), and by having a Y-shaped light mark on the snout (vs. lacking a Y-shaped light mark on the snout). Parotocinclus variola is distinguished from all other congeners from the Amazon, Orinoco and the Guianas by having a pigmentation pattern consisting of conspicuous dark dots smaller than a pupil diameter, broadly distributed dorsally and ventrally (vs. the absence of such pigmentation pattern). Parotocinclus variola is further distinguished form $P$. eppleyi (Orinoco basin), P. longirostris, $P$. amazonensis (Amazon basin) and P. britskii (Orinoco and coastal drainages of the Guianas) by having the central abdominal plates arranged in a single series between the lateral abdominal plates, from the coracoid to the preanal plate and with a wide naked area at the pelvic-fin base ( $v s$. central abdominal plates arranged in two or more series between the lateral abdominal plates and without wide naked area at the pelvic-fin base). It is further diagnosed from $P$. eppleyi, $P$. longirostris, and $P$. polyochrus by having a Y-shaped, light mark on the snout only (vs. Y-shaped, light mark present on both the snout and head). Parotocinclus variola also differs from its congeners in having more oral teeth: 38-46 premaxillary and 3946 dentary teeth (vs. 38-42 and 31-38 respectively in $P$. longirostris, 19-29 and 17-23 in P. amazonensis, 15-28 and 16-27 in P. eppleyi, 32-40 and 35-42 in P. polyochrus, and 25-28 and 25-26 in P. britskii).

Description. Proportional measurements in Table 1. Dorsal profile of head concave from snout tip to orbit, convex from orbit to parieto-supraoccipital tip and straight to slightly concave from that point to origin of dorsal fin. Small depression in front of naris, rostrum slightly depressed. Dorsal profile of body straight and posteroventrally slanted from dorsal-fin origin to insertion of caudal fin. Trunk roundly triangular and caudal peduncle rounded to ovoid in cross section, slightly flattened ventrally and compressed caudally. Snout elongated, depressed, with its anterior margin slightly pointed in dorsal view. Body progressively narrowing posteriorly from cleithrum.

Head flat to slightly convex between orbits; dorsal margin of orbit slightly elevated. Eye positioned dorsolaterally, comparatively small with iris operculum vestigial. Posterior tip of parieto-supraoccipital with small patch of slightly enlarged odontodes relative to those of remainder of head and predorsal area. Odontodes on head and trunk otherwise of uniform size and distribution, diverging on snout and converging to parieto-supraoccipital. Enlarged odontodes 
present on most of border of snout, especially on rostral and postrostral plates; enlarged odontodes curved and posteriorly oriented. Cheek canal plate bent and elongated posteroventrally, contacting cleithrum. Lips rounded, narrow, covered with minute papillae except along posterior margin of lower lip; papillae decreasing in size towards lip margin. Lip margin with uniformly distributed papillae. Maxillary barbel short; mostly adnate to lower lip. Teeth slender, bifid. Larger, medial cusp blade-like and slightly rounded, not elongated. Smaller, lateral cusp minute and pointed. Premaxillary teeth 37-46 (40/39); dentary teeth 3946 (-/42); accessory teeth absent.

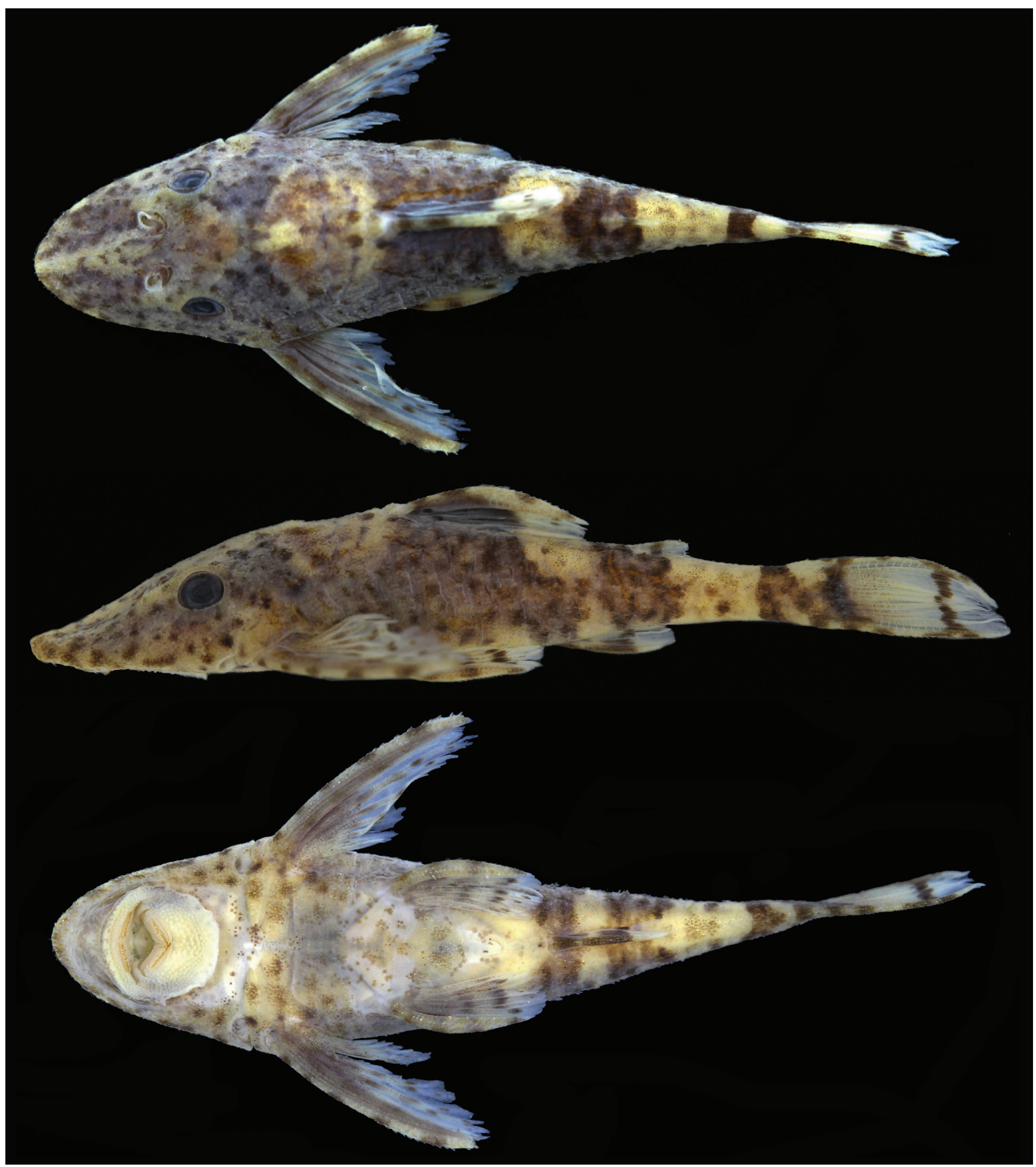

Fig. 1. Holotype of Parotocinclus variola, new species, male, $25.9 \mathrm{~mm}$ SL, ICNMHN 18685. Colombia, Amazonas Department, Letícia, Quebrada Tacana. 
Table 1. Morphometrics of holotype $(\mathrm{H})$ and paratypes $(n=14)$ of Parotocinclus variola as percents of standard length or head length. $\mathrm{SD}=$ standard deviation.

\begin{tabular}{|c|c|c|c|c|c|}
\hline \multirow[b]{2}{*}{ Measurements } & \multirow[b]{2}{*}{$\mathrm{H}$} & \multicolumn{2}{|c|}{ Range } & \multirow[b]{2}{*}{ Mean } & \multirow[b]{2}{*}{ SD } \\
\hline & & Min & Max & & \\
\hline Standard length & 25.9 & 21.8 & 29.3 & 24.8 & - \\
\hline \multicolumn{6}{|c|}{ Percents of standard length } \\
\hline Body depth & 17.6 & 15.6 & 20.1 & 17.9 & 1.04 \\
\hline Predorsal distance & 44.8 & 41.2 & 48.3 & 45.2 & 1.86 \\
\hline Prepelvic distance & 40.7 & 38.6 & 45.0 & 41.7 & 1.79 \\
\hline Preanal distance & 56.4 & 51.7 & 58.3 & 56.0 & 1.83 \\
\hline Preadipose distance & 75.0 & 73.4 & 80.8 & 77.0 & 1.99 \\
\hline Dorsal-fin spine length & 20.1 & 17.1 & 23.9 & 20.3 & 1.93 \\
\hline Anal-fin unbranched ray length & 11.9 & 9.7 & 13.4 & 11.3 & 0.94 \\
\hline Adipose-fin spine length & 6.9 & 6.1 & 8.2 & 7.0 & 0.50 \\
\hline Pectoral-fin spine length & 18.8 & 17.0 & 21.9 & 19.5 & 1.46 \\
\hline Pectoral-fin spine depth & 0.8 & 0.6 & 1.2 & 0.8 & 0.14 \\
\hline Caudal peduncle depth & 6.7 & 6.4 & 7.6 & 6.9 & 0.33 \\
\hline Dorsal-adipose fin distance & 13.7 & 10.8 & 16.6 & 14.3 & 1.51 \\
\hline Dorsal-fin base length & 13.8 & 9.6 & 13.8 & 11.2 & 1.16 \\
\hline Lower caudal-fin principal ray & 10.5 & 10.5 & 17.5 & 14.0 & 1.64 \\
\hline Cleithral width & 19.3 & 17.6 & 22.2 & 20.4 & 1.26 \\
\hline Head length & 28.4 & 28.4 & 32.5 & 30.0 & 1.27 \\
\hline \multicolumn{6}{|c|}{ Percents of head length } \\
\hline Head depth & 60.0 & 59.3 & 62.8 & 61.4 & 1.38 \\
\hline Interorbital distance & 45.7 & 41.4 & 47.8 & 45.3 & 1.72 \\
\hline Orbital horizontal diameter & 18.9 & 15.8 & 20.1 & 17.9 & 1.10 \\
\hline Snout length & 75.8 & 70.1 & 75.8 & 73.2 & 1.98 \\
\hline Internareal distance & 11.4 & 10.0 & 13.7 & 11.9 & 1.05 \\
\hline
\end{tabular}

Body entirely covered by dermal plates except for ventral surface of head around lips, area immediately surrounding pectoral- and pelvic-fin insertions, and area around anus. Dermal plates of body uniformly covered with small odontodes arranged in inconspicuous longitudinal rows except on abdominal plates, where odontodes are irregularly distributed. Lateral plates arranged in five longitudinal series on trunk. Dorsal plate series complete, with 19 plates; middorsal series incomplete, with seven plates; middle series complete, with two ossified tubes and 22 plates. Lateral line with six anterior plates bearing canal and followed by 1-2 unperforated plates, then 13-14 posterior plates bearing canal, and one terminal plate without canal. Mid-ventral series incomplete with 14-15 plates; series terminating near origin of adipose fin. Ventral series complete and continuous from pelvic-fin origin to caudal-fin base, with 19-20 plates. Predorsal plates forming two series anterior to nuchal plate. Single preadipose azygous plate. Coracoid completely exposed ventrally. Cleithrum mostly exposed but covered by skin medially; arrector fossa completely closed. Lateral abdominal plates 2-4 (3/4); plates elongate, clearly arranged in line between coracoid and pelvic-fin origin. Middle abdominal plates 6-11 (7), laterally elongate, arranged in one longitudinal series covering most of abdominal surface between pectoral girdle and preanal shield. Preanal shield well developed, formed by 3-6 (4) round plates (Fig. 2). Total vertebrae 27.

Dorsal-fin rays I,7; spine conspicuously arched. Dorsalfin origin at vertical slightly posterior to pelvic-fin origin. Dorsal-fin spinelet present, plate-like and triangular. Dorsal-fin locking mechanism non-functional. Adipose fin small. Pectoral-fin rays I,6. Large spine slightly arched; tip of adpressed spine reaching between middle and distal third of pelvic fin. Pectoral-fin axillary slit present, with large slanted opening ventral to tip of posterior process of cleithrum. Pelvic-fin rays i,5. Fin short, with tip of adpressed fin reaching to, or falling short of, anal-fin origin. Adult males with fleshy flap along posterodorsal margin of thickened first pelvic-fin ray. Anal-fin rays i,5. Caudal-fin rays $i, 14, i$, with lower unbranched ray slightly longer than upper.

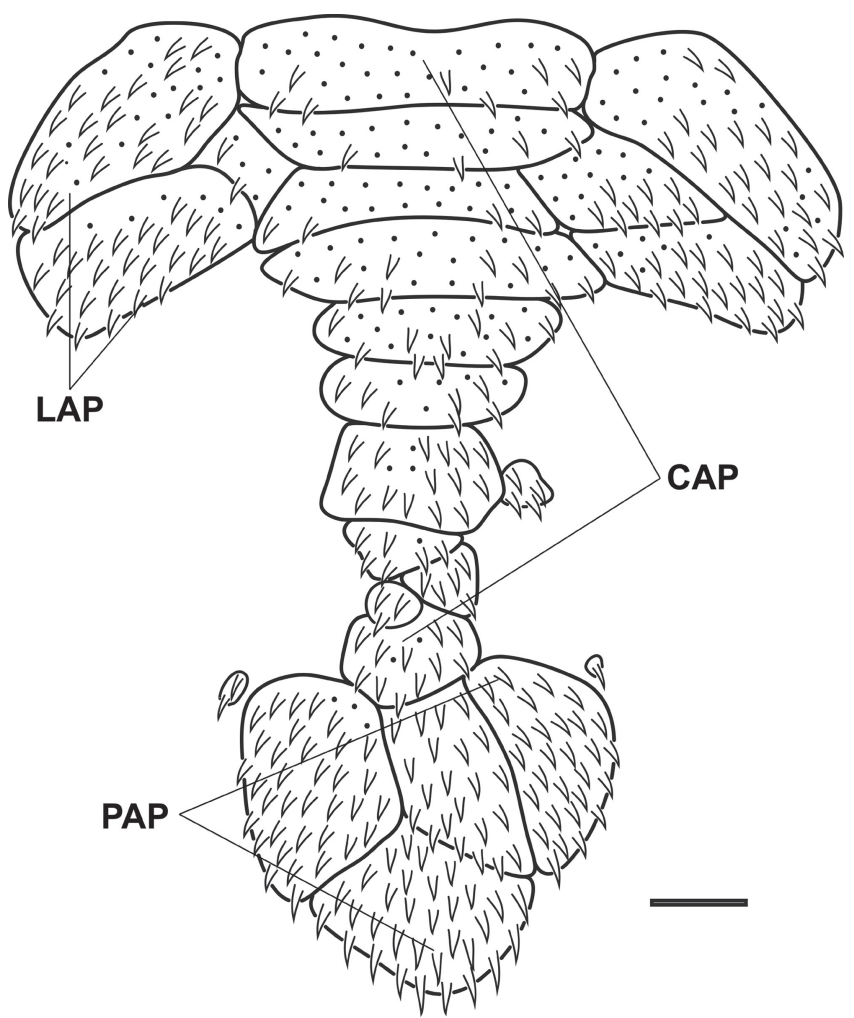

Fig. 2. Abdominal plates of Parotocinclus variola, paratype, MCP 48245, $26.5 \mathrm{~mm}$ SL. LAP - Lateral abdominal plates; CAP - Central abdominal plates; PAP - Preanal plates. Scale bar $=0.5 \mathrm{~mm}$.

Color in alcohol. Dorsal and lateral portions of head and trunk dark brown with ventral surface lighter. Dorsal surface of snout with Y-shaped light mark in front of eyes. Posterior portion of parieto-supraoccipital and predorsal region conspicuously lighter than surrounding areas. Trunk with three conspicuous light cream bars, extending transversely 
from dorsal midline to ventral surface. First bar situated on posterior third of dorsal fin; its anterior margin continuing as thinner bar below lateral line and reaching ventral midline. Second light bar longest, on caudal peduncle immediately posterior to anal fin and reaching ventral midline. Third bar shortest, immediately anterior to caudal fin and variably reaching ventral surface. Superposed on above pattern, dorsal and most of ventral surface covered with small dots smaller then pupil diameter, formed by concentration of black chromatophores and giving sprinkled pattern. Fins with transverse, inconspicuous brown bands formed by concentration of chromatophores on rays; bands more visible on leading rays. Dorsal-fin spine with 4-5 dark spots, fin membrane with large dark brown triangular spot on anterior half; one or two irregular dark bands posteriorly. Pectoral-fin spine with 5-6 dark spots, branched rays with 2-3 irregular bands. Pelvic and anal fins with 3-4 irregular bands. Adipose-fin spine with one dark spot. Caudal fin mostly hyaline with dark band at base and conspicuous dark brown transverse band on posterior half.

Distribution and habitat. Parotocinclus variola is known from one locality in the Quebrada Tacana, a small creek tributary to the rio Amazonas about $6.5 \mathrm{~km}$ by the road from Leticia to Tarapacá, Amazonas Department, in southern Colombia (Fig. 3). The Quebrada Tacana is a blackwater creek with sandy bottom and the collecting station is located on the Terra Firme, above the level of the yearly seasonal flood (Galvis et al., 2006). Average rainfall in the area is $3,400 \mathrm{~mm} /$ year and average temperature is $25.5^{\circ} \mathrm{C}$. The potential distribution of this species is likely to include other such habitats in the area, both in Colombia and Brazil.

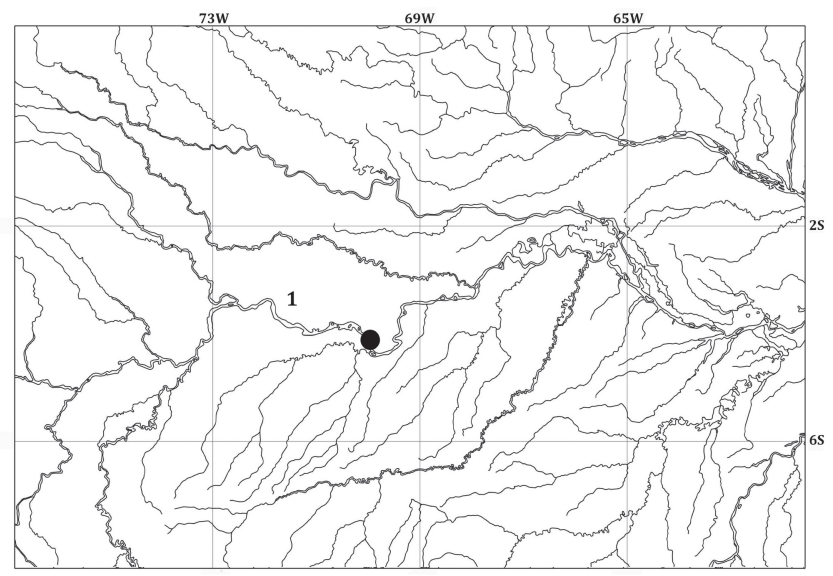

Fig. 3. Drainage map of the upper Amazon basin showing the type locality of Parotocinclus variola. 1 - Amazon River.

Etymology. Parotocinclus variola is named from the Latin variola, smallpox, spotted, in allusion to the dark dots that cover all dorsal and ventral body surfaces. A noun in apposition.
Conservation status. The conservation status of Parotocinclus variola is uncertain based on the limited knowledge of its geographic distribution. The species is so far known from the type-locality only, but it is probably more widely distributed in blackwater creeks and rivers in western Amazonia in Colombia, Peru and Brazil. Considering that important threats to the species were not detected in the area, P. variola would be classified as Least Concern (LC) according to the International Union for Conservation of Nature (IUCN) categories and criteria (IUCN Standards and Petitions Subcommittee, 2014). Additional collecting efforts should be conducted in that region in order to better understand the geographic distribution of this species.

\section{Acknowledgments}

We are grateful to José Iván Mojica and Germán Galvis (ICNMHN, Bogotá) for calling our attention to this species, for the loan and donation of specimens and for providing additional information, and to Carlos A. S. Lucena for help provided at the MCP fish collection. PLA is partially funded by the Conselho Nacional de Desenvolvimento Científico e Tecnológico - CNPq (Process \#483060/2013-5) and the Fundação de Amparo à Pesquisa do Estado do Rio Grande do Sul - FAPERGS (Process \# 11/1220-7), and RER is partially funded by CNPq (processes \#305180/2010-0 and \#207038/2013-9) and FAPERGS (process \# 11/0936-5).

\section{References}

Boeseman, M. 1968. The genus Hypostomus Lacépède, 1803, and its Surinam representatives (Siluriformes, Loricariidae). Zoologische Verhandelingen, 99: 1-89.

Boeseman, M. 1974. On two Surinam species of Hypoptopomatinae, both new to science (Loricariidae, Siluriformes, Ostariophysi). Proceedings of the Koninklijke Nederlandse Akademie van Wetenschappen (Series C, Biological and Medical Sciences), 77: 251-271.

Galvis, G., J. I. Mojica, S. R. Duque, C. Castellanos, P. SánchezDuarte, M. Arce, A. Gutiérrez, L. F. Jiménez, M. Santos, S. Vejarano, F. Arbeláez, E. Prieto \& M. Leiva. 2006. Peces del Medio Amazonas. Región de Leticia. Conservación Internacional. Bogotá, Colombia, Editorial Panamericana, Formas e Impressos. Serie de Guías Tropicales de Campo, n. 5.

Garavello, J. C. 1977. Systematics and geographical distribution of the genus Parotocinclus Eigenmann \& Eigenmann, 1889 (Ostariophysi, Loricariidae). Arquivos de Zoologia, 28: 1-37.

Garavello, J. C. 1988. Three new species of Parotocinclus Eigenmann \& Eigenmann, 1889 with comments on their geographical distribution (Pisces, Loricariidae). Naturalia, 13: 117-128.

IUCN Standards and Petitions Subcommittee. 2014. Guidelines for using the IUCN Red List Categories and Criteria. Version 11. Prepared by the Standards and Petitions Subcommittee. Available from http://www.iucnredlist.org/documents/ RedListGuidelines.pdf (Date of access - 12 February 2015).

Lehmann, P. \& R. E. Reis. 2012. A new species of Parotocinclus (Siluriformes: Loricariidae) from the upper Rio São Francisco, Brazil. Zootaxa, 3390: 56-64. 
Lehmann A., P., B. K. Braun, E. H. L. Pereira \& R. E. Reis. 2013. A new species of the Hypoptopomatinae catfish Parotocinclus (Siluriformes: Loricariidae), from the headwaters of the Rio Jequitinhonha, Brazil. Copeia, 2013: 435-440.

Lehmann A., P., H. Lazzarotto \& R. E. Reis. 2014. Parotocinclus halbothi, a new species of small armored catfish (Loricariidae: Hypoptopomatinae), from the Trombetas and Marowijne River basins, in Brazil and Suriname. Neotropical Ichthyology, 12: $27-33$.

Schaefer, S. A. 1997. The Neotropical cascudinhos: systematics and biogeography of the Otocinclus catfishes (Siluriformes: Loricariidae). Proceedings of the Academy of Natural Sciences of Philadelphia, 148: 1-120.

Schaefer, S. A. 1988. A new species of the loricariid genus Parotocinclusfrom southern Venezuela (Pisces: Siluroidei). Copeia, 1988: 182-188.
Schaefer, S. A. and F. Provenzano. 1993. The Guyana Shield Parotocinclus: systematics, biogeography, and description of a new Venezuelan species (Siluroidei: Loricariidae). Ichthyological Exploration of Freshwaters, 4: 39-56.

Schmidt, R. E. and C. J., Jr. Ferraris. 1985. A new species of Parotocinclus (Pisces: Loricariidae) from Guyana. Proceedings of the Biological Society of Washington, 98: 341-346.

Taylor, W. R. \& G. C. Van Dyke. 1985. Revised procedures for staining and clearing small fishes and other vertebrates for bone and cartilage study. Cybium, 9: 107-119.

Submitted August 08, 2014

Accepted September 24, 2014 by Hernán López-Fernández

Published March 31, 2015 